\section{THE EVOLUTION OF FOREARC STRUCTURES ALONG AN OBLIQUE CONVERGENT MARGIN, CENTRAL ALEUTIAN ARC}

Holly F. Ryan and David W. Scholl

U. S. Geological Survey, Menlo Park, California

Abstract. Multichannel seismic reflection data were used to determine the evolutionary history of the forearc region of the central Aleutian Ridge. Since at least late Miocene time this sector of the ridge has been obliquely underthrust $30^{\circ}$ west of orthogonal convergence by the northwestward converging Pacific plate at a rate of $80-90 \mathrm{~km} / \mathrm{m}$.y. Our data indicate that prior to late Eocene time the forearc region was composed of rocks of the arc massif thinly mantled by slope deposits; the forearc region probably lacked both major depositional basins and a tectonically attached accretionary prism of offscraped oceanic deposits. Beginning in latest Miocene or earliest Pliocene time, a zone of outer-arc structural highs and a forearc basin began to form. Formation of these companion intraarc structures may be linked to the late Neogene growth of an accretionary wedge that formed as the result of the deposition of a thick turbidite wedge in the Aleutian Trench. Initial structures of the zone of outer-arc highs formed as the thickening wedge underran, compressively deformed, and uplifted the seaward edge of the arc massif above a landward dipping backstop thrust. Forearc basin strata ponded arcward of the elevating zone of outer-arc highs. However, most younger structures of the zone of outer-arc highs cannot be ascribed simply to the orthogonal effects of an underrunning wedge. Oblique convergence created a major right-lateral shear zone (the Hawley Ridge shear zone) that longitudinally disrupted the zone of outerarc highs, truncating the seaward flank of the forearc basin and shearing the southern limb of Hawley Ridge, an exceptionally large antiformal outer-arc high structure. Slivers of

This paper is not subject to U. S. copyright. Published in 1989 by the American Geophysical Union.

Paper number 89TC00246. forearc basement rocks and overlying strata have been transported along the shear zone that is flanked by differentially elevated structures attributed to localized transpressive and transtensional processes. Uplift of Hawley Ridge may be related to the thickening of the arc massif by westward directed basement duplexes. In addition, the forearc is disrupted by structures transverse to the margin that occur where unusually high-stress accumulations have resulted in the rupture of repeated great earthquakes. It is likely that many ancient active margins evolved in tectonic and depositional settings similar to those of the central Aleutian Ridge. Great structural complexity, including the close juxtaposition of coeval structures recording compression, extension, differential vertical movements, and strike-slip displacement, should be expected, even within areas of generally kindred tectonostratigraphic terranes.

\section{INTRODUCTION}

Along convergent margins with high trench sedimentation rates the underthrusting of oceanic crust typically forms an accretionary complex and associated outer-arc structural high that uplifts the seaward flank of a forearc basin [c.g., Karig and Sharman, 1975; Seeley, 1978]. Davis et al. [1983] have successfully modeled the mechanical behavior of an accretionary complex as a tapered wedge of Coulomb material that deforms to maintain a critical taper. Although the model predicts the taper of the toe of the wedge, it does not account for the change of slope of the wedge associated with the the outer-arc structural high. The formation of outer-arc structural highs and forearc basins is dependent, in part, on how the accretionary wedge is attached to the older bedrock framework of the arc. Both landward dipping [e.g., Dickinson and Seeley, 1979, Brandon, 1986, von Huene et al., 

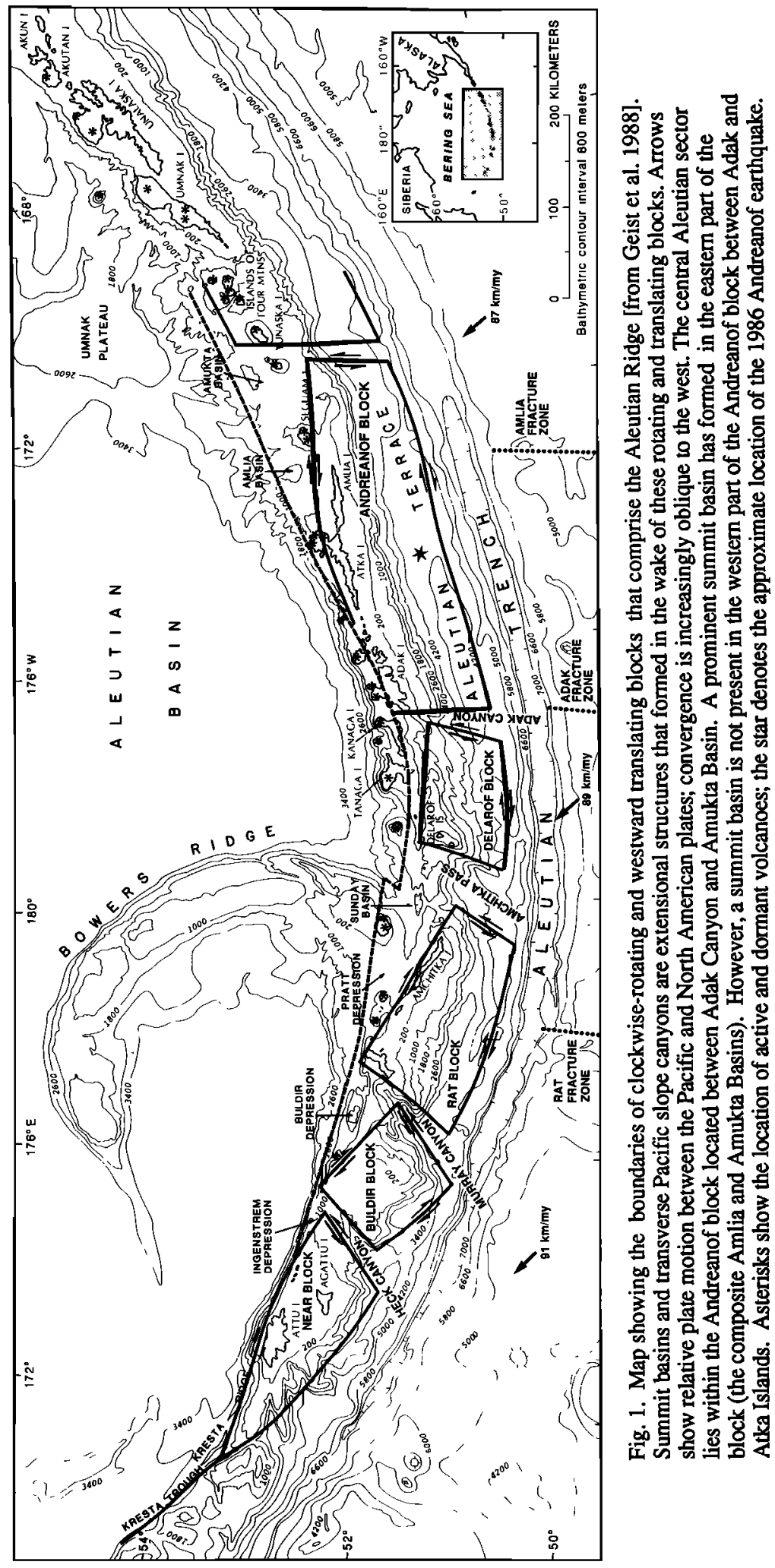


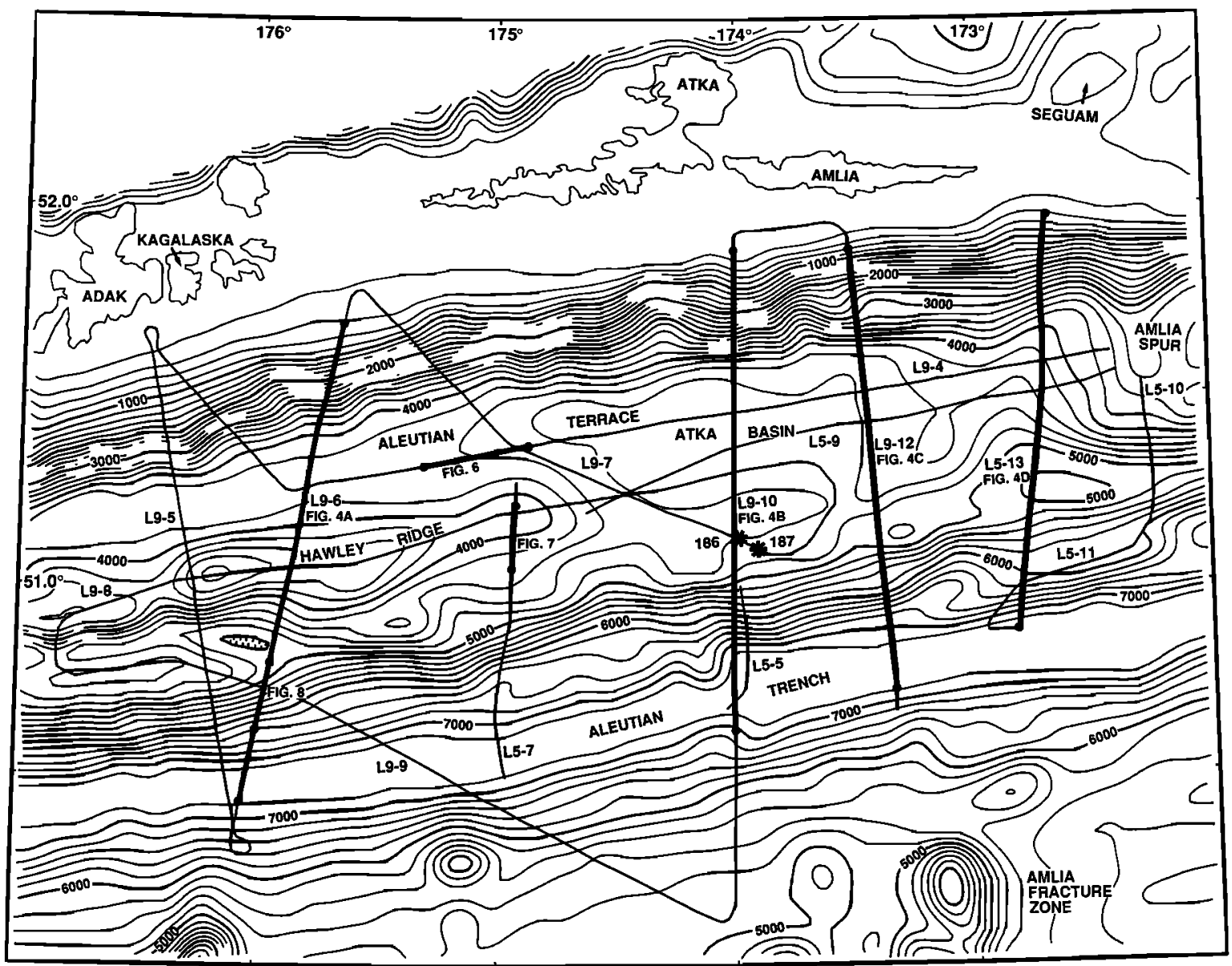

Fig. 2a. Trackline map of multichannel seismic reflection data collected in the Amlia corridor of the Aleutian forearc. The bathymetric contour interval is $200 \mathrm{~m}$. Locations of Deep Sea Drilling Project (DSDP) sites 186 and 187 are shown by asterisks. Locations of seismic sections displayed in other figures are shown.

1988, and this paper] and seaward dipping [e.g., Le Pichon et al., 1982; Silver et al., 1985; Westbrook et al., 1988; Zoback and Wentworth, 1986; Silver and Reed, 1988; Byme et al., 1988] thrust faults have been proposed to form the backstop; the geometry of the backstop not only controls the structural style of the outer-arc high, but affects the mechanical behavior of the accretionary complex.

The deformation of most forearcs cannot, however, be explained by the simple accretion of material against a backstop. Most convergent margins have a protracted tectonic history that may include periods of tectonic erosion and/or accretion [Moore and Silver, 1987, and references therein]. In addition, evidence is accumulating that strike-slip faults are important in the deformational history of many convergent margin forearcs [e.g., Fitch, 1972; Beck, 1986; Jarrard, 1986; Karig et al., 1986; Lewis et al., 1988]. Geist et al. [1988] have documented the importance of strike-slip faulting and attendant block rotations in the deformation of the Aleutian Ridge (Figure 1).

A prominent zone of outer-arc highs flanking a forearc basin is present beneath the Aleutian Terrace along the cen- tral Aleutian forearc. This paper deals with the origin and structural evolution of these outer-arc structures on the basis of the interpretation of field geophysical and geological data. We present data to show that (1) the central Aleutian forearc has been an accretionary margin since only Pliocene time, although subduction has been continuous since Eocene time, (2) the accretionary complex is attached to the arc massif beneath a landward dipping backstop, and (3) oblique, but rapid, plate convergence along the margin has resulted in the formation of a major shear zone that cuts the zone of outerarc highs.

\section{DATA ACQUISITION AND PROCESSING}

In 1980 and 1981, the U. S. Geological Survey collected $1850 \mathrm{~km}$ of 24-fold multichannel seismic reflection (MCS) data on the R/V S. P. Lee in the central Aleutian forearc (Figure 2a). The energy source was a tuned array of five 2000-psi (138 bar) air guns having a total volume of 1315 in $^{3}$ (21.5 li). The data were collected using a $2400-\mathrm{m}$-long hydrophone streamer and GUS $\mathbf{4 2 0 0}$ digital acquisition sys- 


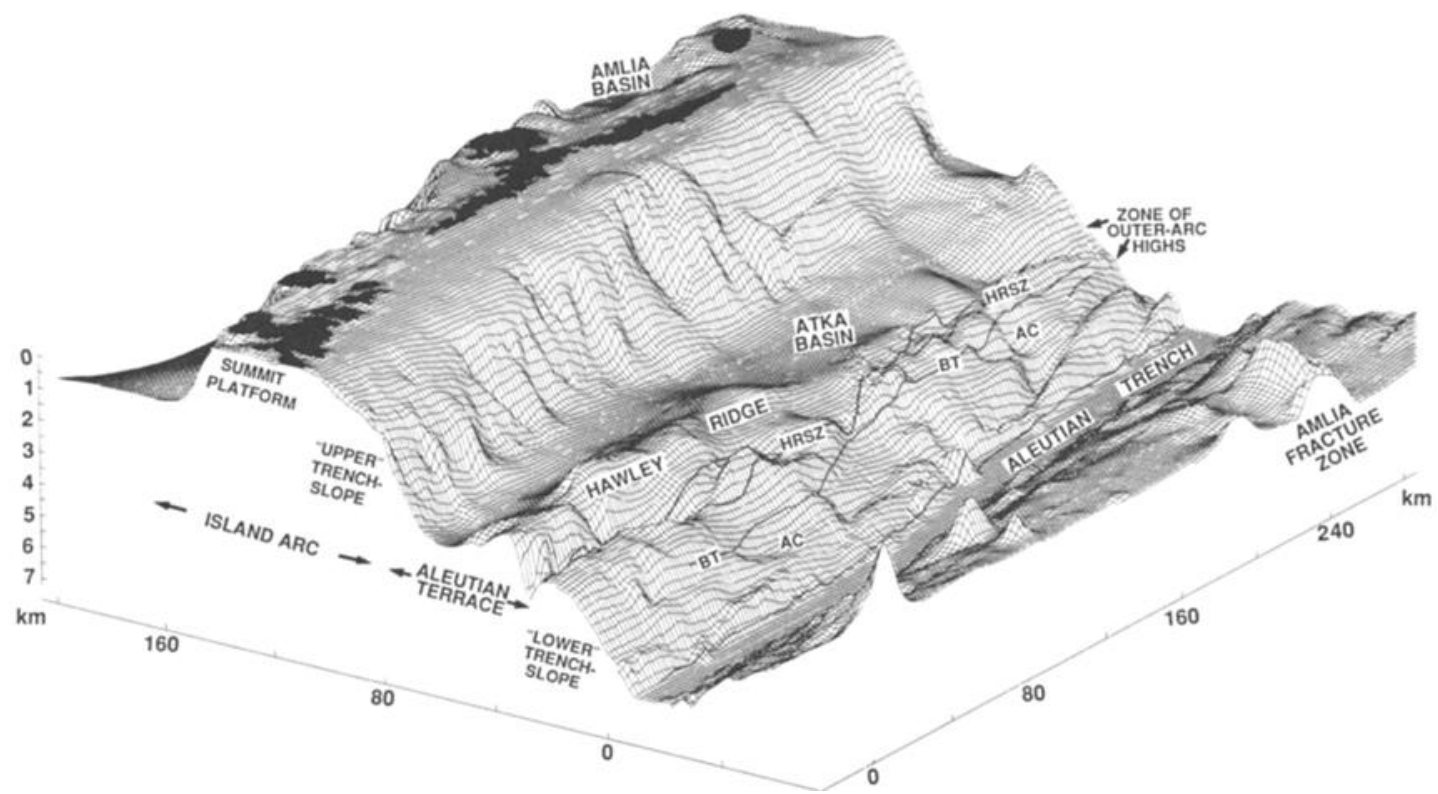

Fig. 2b. Perspective bathymetric diagram illustrating the major geomorphic features over the same area as shown in Figure 2a (bathymetry from Department of Commerce [1973a]). Major geomorphic features include the Aleutian Terrace, Hawley Ridge, and Atka Basin. HRSZ, Hawley Ridge shear zone; BT, backstop thrust. AC shows location of outcropping accretionary complex. Vertical exaggeration (VE) is 10:1.

tem. Shot spacing ( $50 \mathrm{~m})$ and ship location were controlled by an integrated satellite-LORAN $C$ navigational system. Gravity, magnetic, and sonobuoy refraction data were also collected.

Initial processing of the MCS data included demultiplexing, velocity analysis, stacking, filtering, and finite difference poststack migration. Various processing techniques including prestack migration, frequency domain migration, and depth conversion were also applied to the data to better image structures beneath a structurally complex zone of outer-arc highs. Velocities used for the depth conversions were determined from sonobuoy refraction data and interval velocity data derived from dip-corrected and smoothed normalmoveout velocities.

\section{TECTONIC AND GEOMORPHIC SETTING}

The sector of the central Aleutian forearc studied in this paper is located south of the Andreanof Islands between $172^{\circ}$ and $177^{\circ} \mathrm{W}$ longitude, extending from Adak Island eastward approximately $300 \mathrm{~km}$ to Amlia Island (Figures 1 and 2). Along the Amlia to Adak section of the Aleutian Ridge the North American plate is underthrust by the Pacific plate at 83 $\mathrm{km} / \mathrm{m}$.y. and at an angle of $30^{\circ}$ oblique to the trend of the trench axis and arc (Figure 1) [Minster and Jordan, 1978]. However, if the pole of rotation of Engebretson et al. [1986] is used, the rate is $87 \mathrm{~km} / \mathrm{m}$.y. at a more northerly (less oblique) direction. Magnetic anomalies indicate that the underthrusting Pacific plate is Paleogene in age and is progressively older to the south [Grim and Erickson, 1969]. The north trending Amlia and Adak fracture zones intersect the trench at $173^{\circ} \mathrm{W}$ and $177.5^{\circ} \mathrm{W}$, respectively (Figure 1). The Amlia fracture zone offsets isochrons $220 \mathrm{~km}$, and Adak fracture zone shows $30 \mathrm{~km}$ of offset, both are offset in a left-lateral sense [Grim and Erickson, 1969].

Three major geomorphic provinces dominate the Aleutian Ridge: the Aleutian Island Arc, the Aleutian Terrace, and the lower landward slope of the Aleutian Trench (Figure 2b). The summit of the arc is a wave-plained platform crested by islands. The southern side of the platform is gently tilted to the south; especially between Adak and western Atka Islands (Figure 2b). Amlia Basin occurs along the north edge of the summit platform north of Amlia Island (Figure 2).

The upper trench slope descends relatively steeply $\left(5^{\circ}-10^{\circ}\right)$ between the edge of the summit platform and the Aleutian Terrace at about $4 \mathrm{~km}$ depth. Along the ridge, large submarine canyons, such as Adak Canyon, disrupt the lateral continuity of the upper trench slope (Figures 1 and 3). Only relatively small canyons cut the upper slope between Adak and Amlia Islands. East of Adak Canyon, Geologic LongRange Inclined Asdic (GLORIA) sidescan sonar images reveal a highly reflective upper trench slope with little evidence for mass wasting (Figure 3) [Bohannon et al., 1987].

At the base of the upper trench slope is the platform of the Aleutian Terrace. Atka Basin, which measures $30 \mathrm{~km}$ by 40 $\mathbf{k m}$, is the major geomorphic depression of the Aleutian Terrace in this area. West of Atka Basin lies Hawley Ridge, a prominent bathymetric feature that is approximately $150 \mathrm{~km}$ long and $25 \mathrm{~km}$ wide (Figure 2). A narrow ( $<25 \mathrm{~km}$ wide) basinal area exists north of Hawley Ridge (Figure 2). East of 


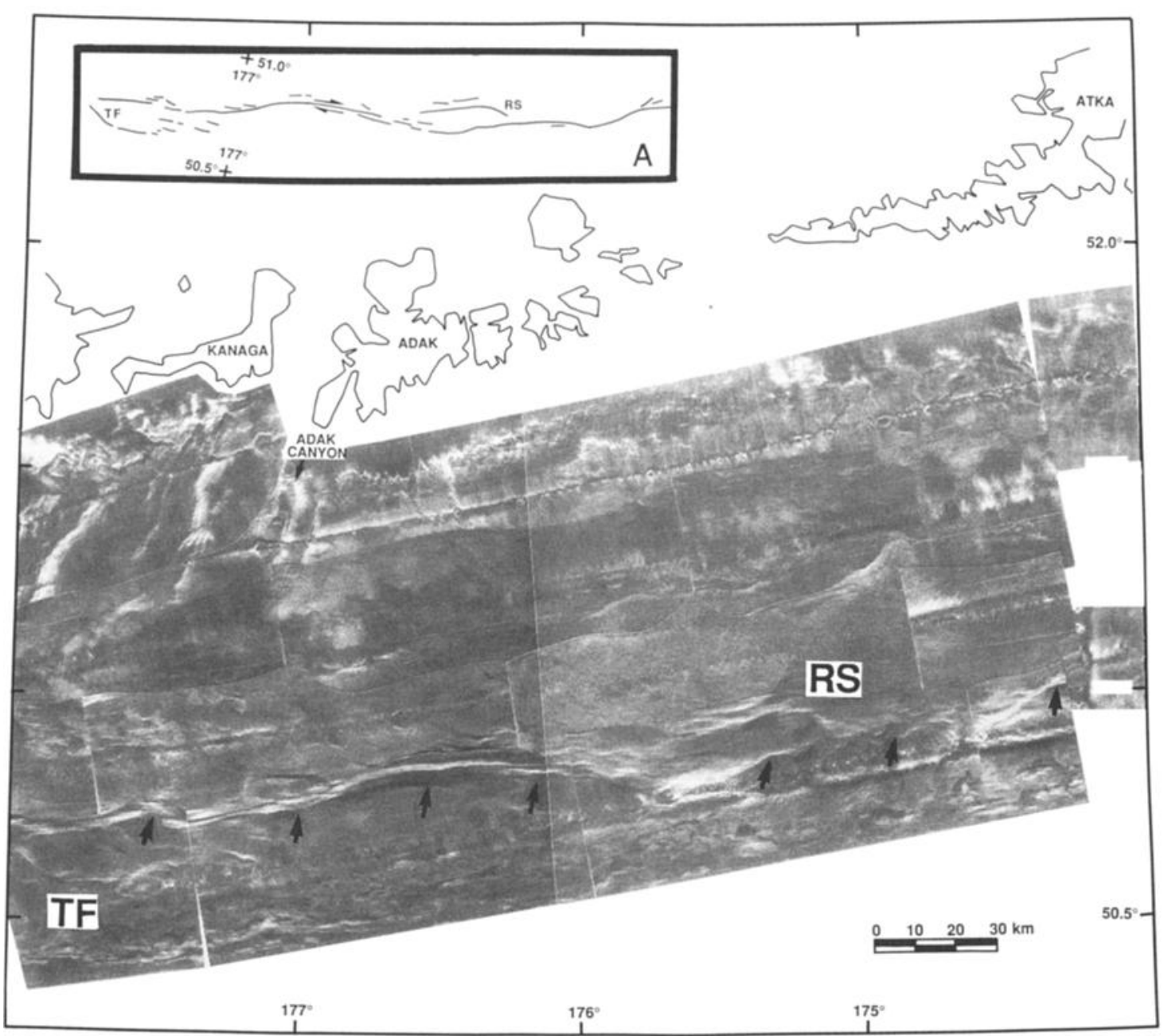

Fig. 3. Preliminary GLORIA mosaic covering a portion of the central Aleutian forearc that shows the Hawley Ridge shear zone (delineated by arrows); the shear zone is the most pronounced feature imaged in the forearc. The western edge of the Andreanof block is at Adak Canyon. West of Adak Canyon, the upper trench slope is cut by numerous transverse canyons, whereas canyons of a similar size are not present east of Adak Canyon. Inset " $A$ " shows a line drawing interpretation of the shear zone. The line drawing illustrates the sinuous nature of the fault and shows the possible presence within the shear zone of tension fractures (TF) and Riedel shears (RS).

Atka Basin the lateral continuity of the Aleutian Terrace is disrupted by Amlia Spur, a transverse bathymetric high (Figure 2). The southern edge of the Aleutian Terrace is marked by a conspicuous seafloor scar (delineated by arrows in Figure 3). South of the Aleutian Terrace, the lower trench slope is characterized by a series of narrow, discontinuous ridges that descend steplike to the planar floor of the Aleutian Trench at about $7300 \mathrm{~m}$ depth (Figure 2b).

\section{GEOLOGIC SETTING}

The geologic framework and evolution of the Aleutian Ridge has been discussed by Scholl et al. [1982, 1983a, b,
1987] and Vallier et al. [1989]. They have divided the geology of the central Aleutian forearc into three chronostratigraphic units: a lower series (Eocene and possibly older), a middle series (Oligocene and Miocene) and an upper series (Pliocene and Quaternary); the series are distinguished on MCS profiles by their structural and stratigraphic relations (Figure 4). The ages of the series are based on paleontologic and radiometric dating of rocks recovered from insular and submerged outcrops in the Adak-Amlia region that can be tied to MCS profiles. The following is a brief summary of each of the time correlative series that is germane to the interpretation of the seismic stratigraphy of the forearc as it applies to the understanding of the structural evolution of the forearc. 


\section{Lower Series}

The lower series forms the bulk of the arc's igneous massif and constitutes the basement of the island arc. Insular exposures of lower series rocks are composed primarily of volcanic and hypabyssal intrusive rocks and coarse-grained volcaniclastic debris [Scholl et al., 1983a, 1987; Vallier et al., 1989]. The oldest subaerially exposed rock of the lower series in the Adak-Amlia sector is of Eocene age [Rubenstone, 1984]. Beneath the flanks of the island arc, lower series rocks dip seaward, parallel to the sea floor, and are truncated by the summit platform along the ridge crest. The lower series can be traced on MCS profiles from insular exposures, seaward beneath the forearc basin of the Aleutian Terrace, to within $1 \mathrm{~km}$ of the sea floor beneath the trenchslope break (Figure 4).

\section{Middle Series}

The rocks of the middle series are thought to be between Oligocene and Miocene age [Scholl et al., 1987], but the actual age limits are not well defined. Exposures of the middle series on the Andreanof Islands are primarily calcalkaline eruptive and plutonic rocks of Oligocene and Miocene age. On Adak and Kagalaska Islands, plutonism occurred in two major episodes at about $33 \mathrm{Ma}$ (Hidden Bay pluton) and at about $13 \mathrm{Ma}$ (Kagalaska pluton) [Citron et al., 1980]. Beneath the submerged flanks of the arc the middle series is a laterally continuous sequence of slope conforming strata deposited with a slight angular discordance on the underlying lower series (Figure 4). The middle series can be traced southward from the upper trench slope, beneath the Aleutian Terrace, to the crest of the zone of outer-arc highs where middle series sedimentary beds are structurally disrupted.

\section{Upper Series}

In the forearc the upper series consists of both the forearc basin strata deposited beneath the Aleutian Terrace and the tectonically thickened sedimentary packages that form the accretionary complex beneath the lower slope of the Aleutian Trench (Figure 4) [McCarthy and Scholl, 1985]. Age constraints for the upper series are provided mainly by Deep Sea Drilling Project (DSDP) sites 186 and 187; the samples at these sites were taken from the seaward flank of the forearc basin (Figure 4c). Site 186 bottomed in lower Pliocene strata that can be traced on MCS profiles to near the base of the upper series underlying the Aleutian Terrace [Creager et al., 1973; Scholl et al., 1987]. The adjacent accretionary complex is undated, but the onset of accretion is assumed to correlate with the time of formation of the Aleutian Terrace forearc basin at about $5 \mathrm{Ma}$ [McCarthy et al., 1984; Harbert et al., 1986].

Three major depocenters are documented beneath the Aleutian Terrace, as determined from an isopach map of the forearc basin and the correlation of seismic reflectors across the basin (Figure 5). Two prominent reflection horizons, US1 and US2 (Figure 4), are tied to DSDP site 186 along profile L9-10 (Figure 4c) and are used to determine the relative ages of the depocenters. US1 is estimated to have been deposited at about 2.4 Ma; US2 has a maximum age of about 900,000 years.

The primary forearc basin depocenter beneath the Aleutian Terrace has migrated to the west and north with time. The oldest and easternmost depocenter (" $A$ " of Figure 5) is presently uplifted west of and beneath Amlia Spur (Figures $4 \mathrm{c}$ and $4 \mathrm{~d}$ ). At least $1 \mathrm{~km}$ of strata were deposited in depocenter A beneath horizon US1. West of depocenter A, preUS1 basin fill is thin and is characterized by laterally discontinuous, poorly reflective events (Figure $4 \mathrm{c}$ ). Although preUS1 strata presumably were deposited over the area north of Hawley Ridge, it is not possible to correlate US1 to the western part of the basin owing to a north striking structural high in the subsurface at the east end of Hawley Ridge (Figure 6).

Between the deposition of US1 and US2, the depocenter of the forearc basin shifted westward to near the location of seismic line L9-10 (" $B$ " of Figure 5). Both the thinning of post-US1 strata in the east (Figures $4 \mathrm{c}$ and $4 \mathrm{~d}$ ) and the presence of an angular unconformity between pre-US1 and postUS1 strata (Figure 4c) indicate that the eastem part of the forearc basin was relatively uplifted before the deposition of US2. Post-US2 strata are thickest north of Hawley Ridge ("C" of Figure 5), where more than $1500 \mathrm{~m}$ of sediment has been deposited in the last 900,000 years (or less) (Figure 6). This depocenter is farther arcward and narrower than the older depocenters because of the relative uplift of Hawley Ridge (Figure 5).

\section{FOREARC STRUCTURE}

The Aleutian Terrace is bordered along its seaward edge by a zone of outer-arc structural highs. Geomorphically, it is a region of bathymetric ridges, swales, and scarps at the

Fig. 4. Multichannel seismic reflection profiles L9-6, L9-10, L9-12, and L5-13, with geopotential profiles and interpreted line drawings. Locations of profiles are shown in Figure $2 \mathrm{a}$. The zone of outer-arc highs (ZOAH) is wider in the west (e.g., Figure 4a) than the east (e.g., Figure 4c). A magnetic high is associated with the ZOAH, which supports the presence of arc basement beneath the ZOAH. Immediately to the south of the shear zone there is an area of highly disrupted reflectors that occurs between the accretionary complex and the shear zone. Common depth point (CDP) spacing is approximately $50 \mathrm{~m}$. Data are migrated, depth converted and coherency filtered; automatic gain control (AGC) has not been applied to the data. LS, top of the lower series; MS, top of the middle series; US1 and US2 are reflectors within the upper series that are correlated to DSDP site 186 (see Figure 4c). The dotted line delineates the shear zone; the surface location of the shear zone is determined from GLORIA data. The dashed line shows the inferred location of the subducting oceanic plate. Both the dotted and dashed lines are queried where uncertain. The inset beneath the interpreted drawings is a simplified line drawing showing major reflectors at a 1:1 VE. 


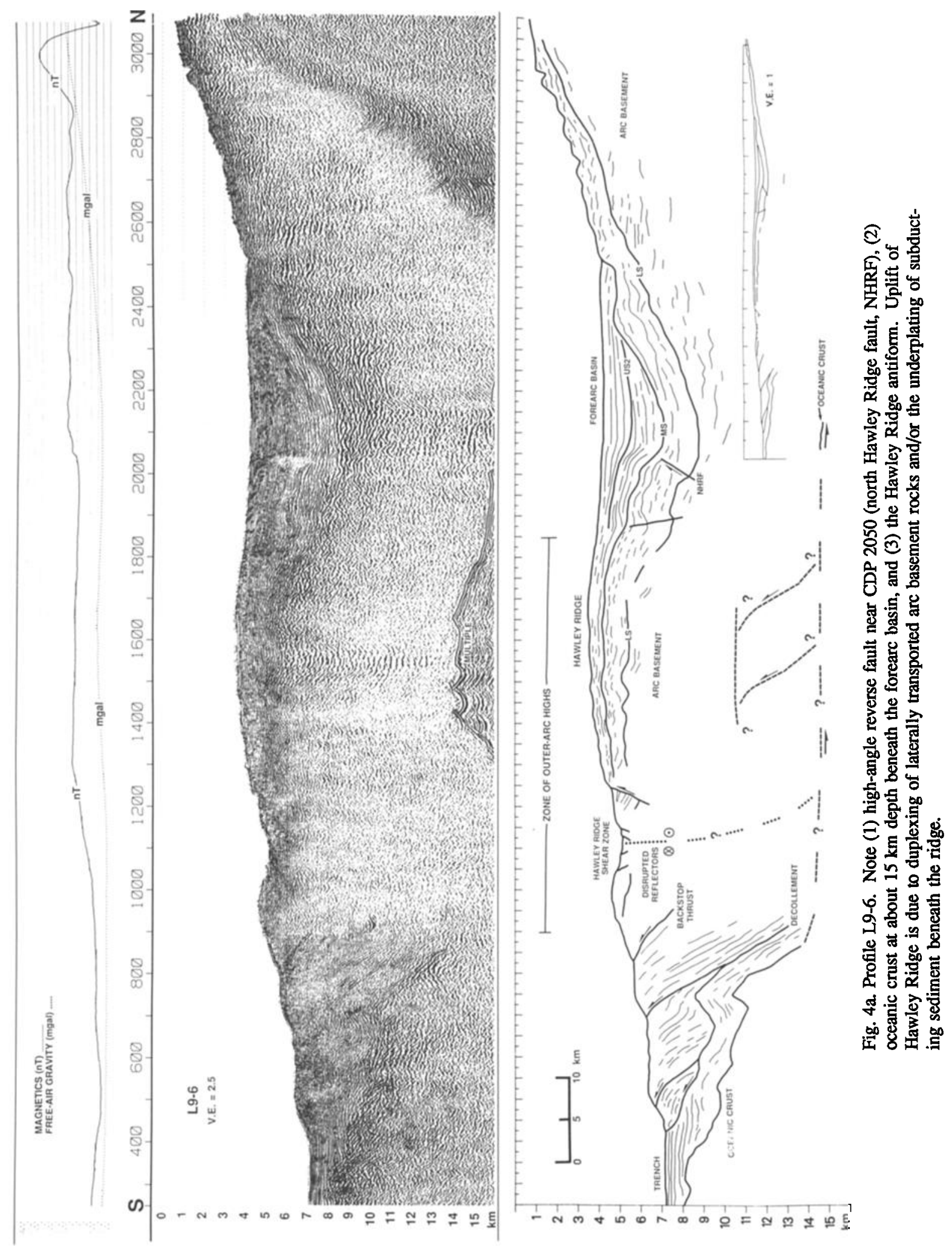



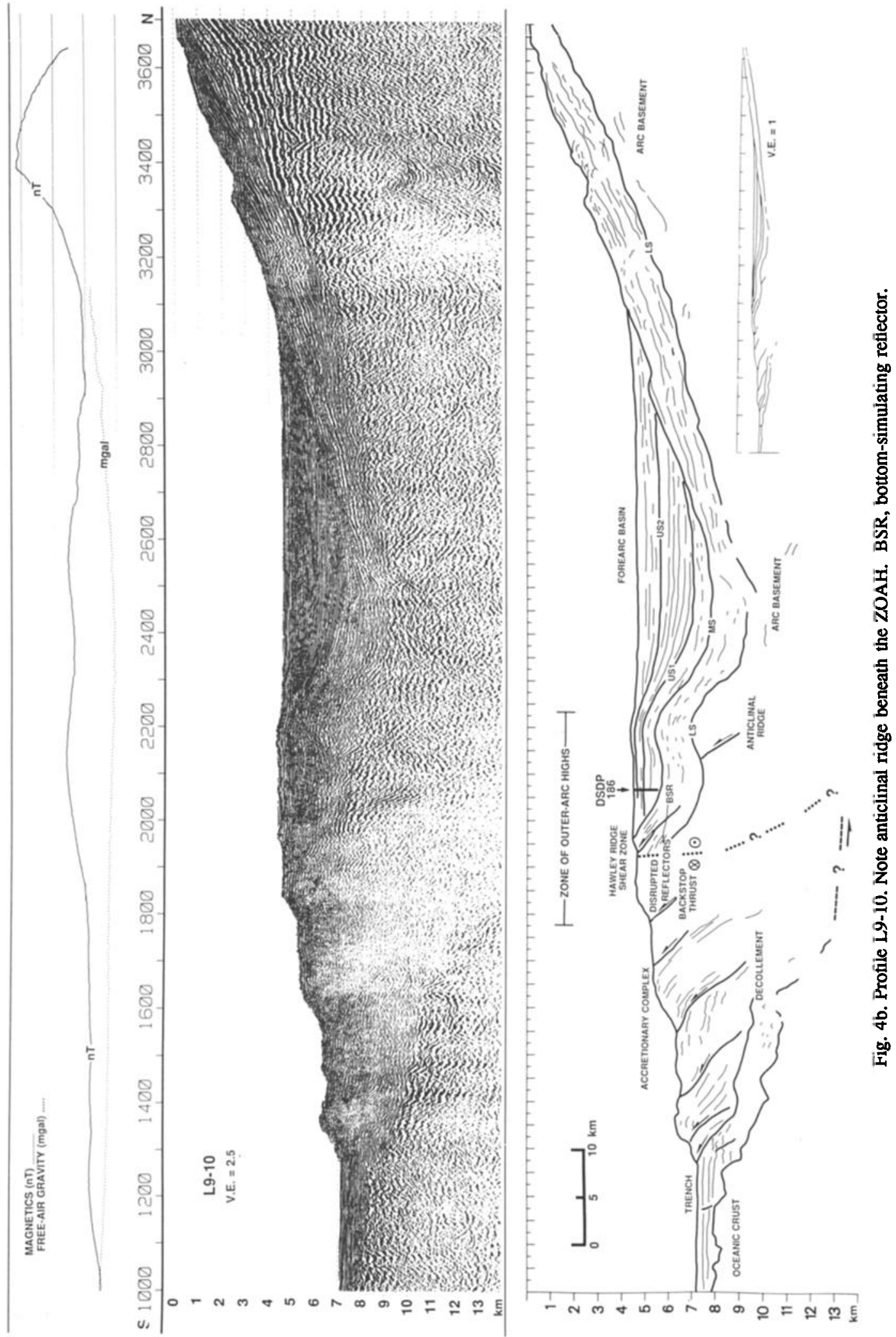

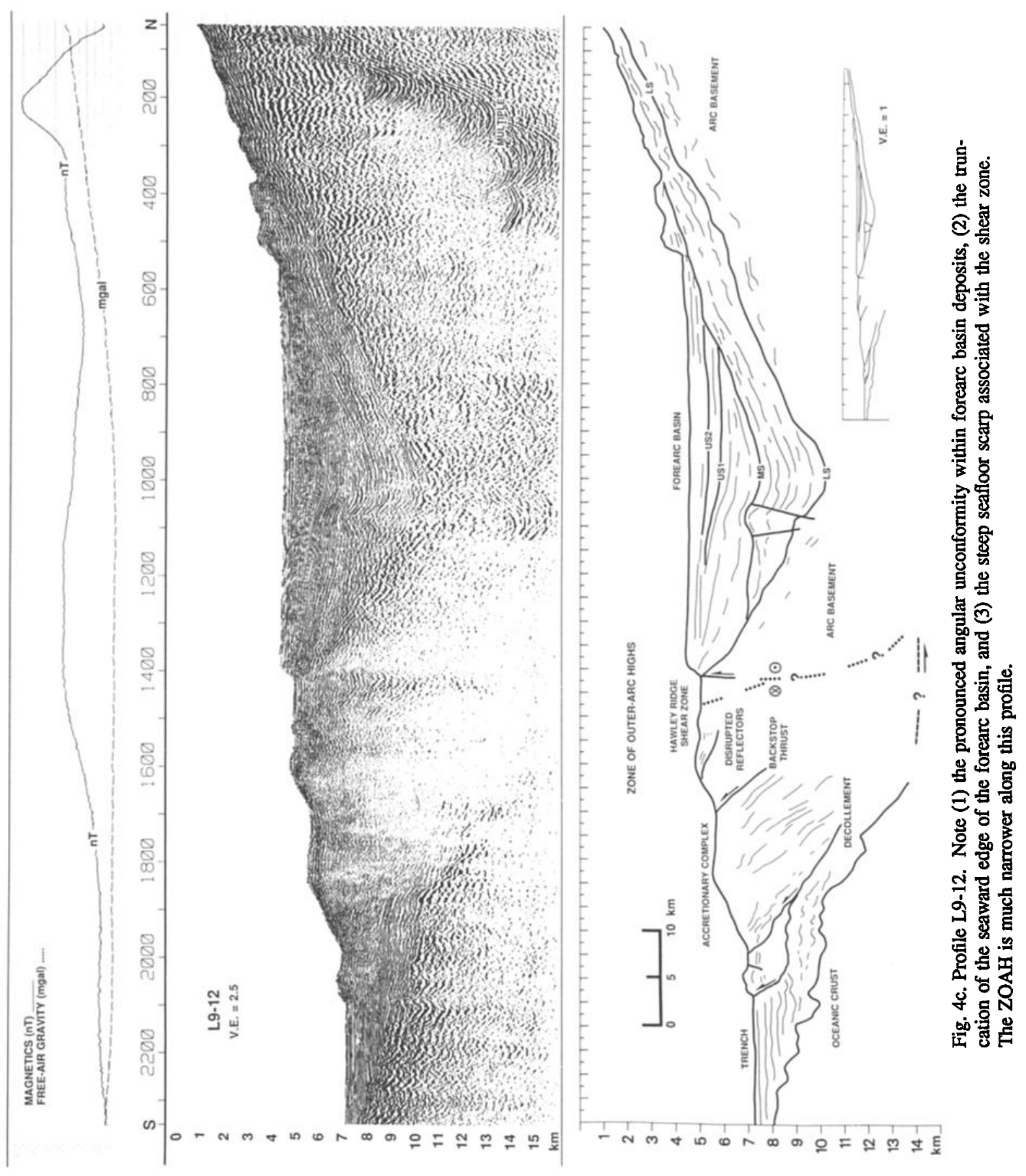

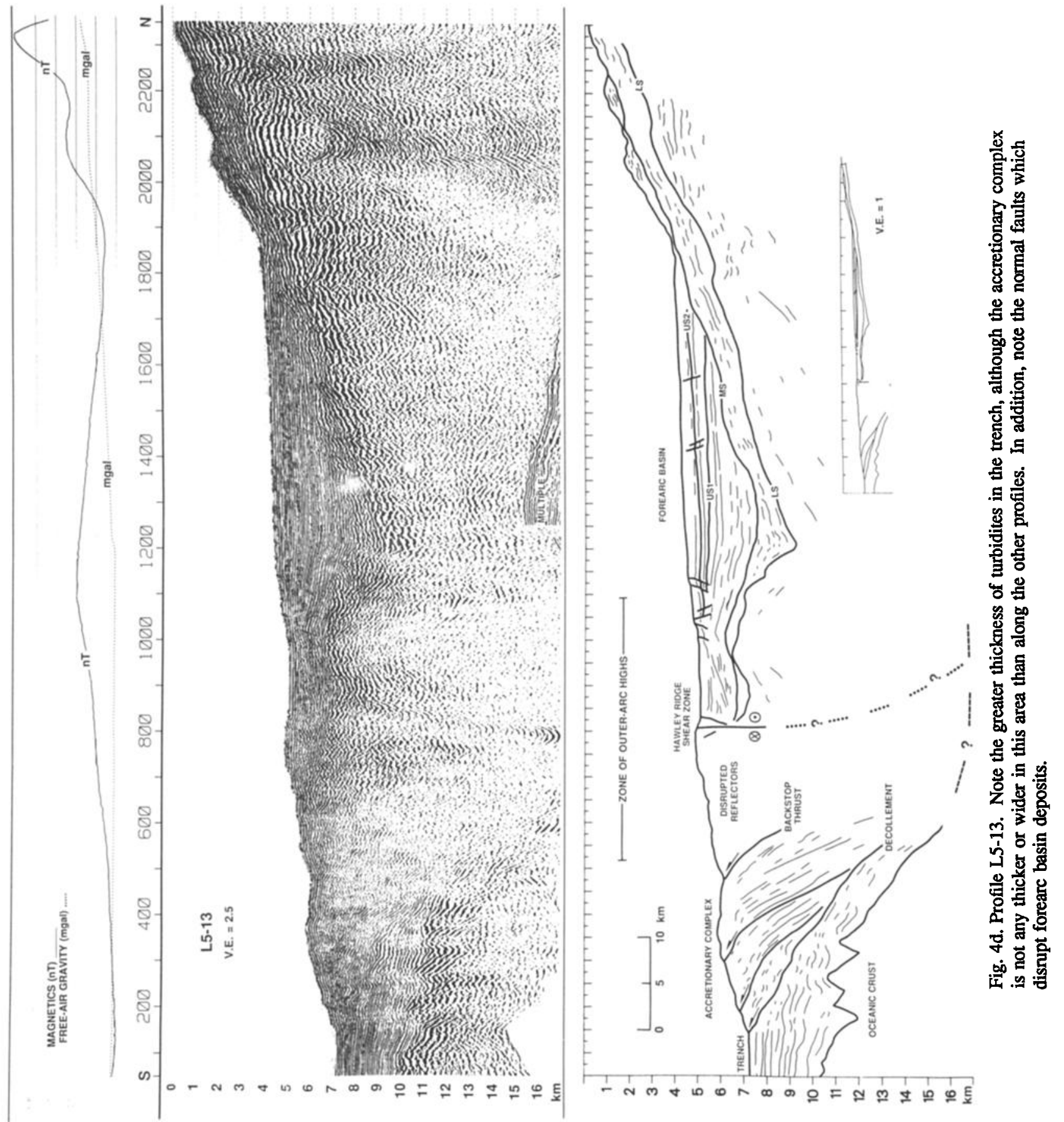


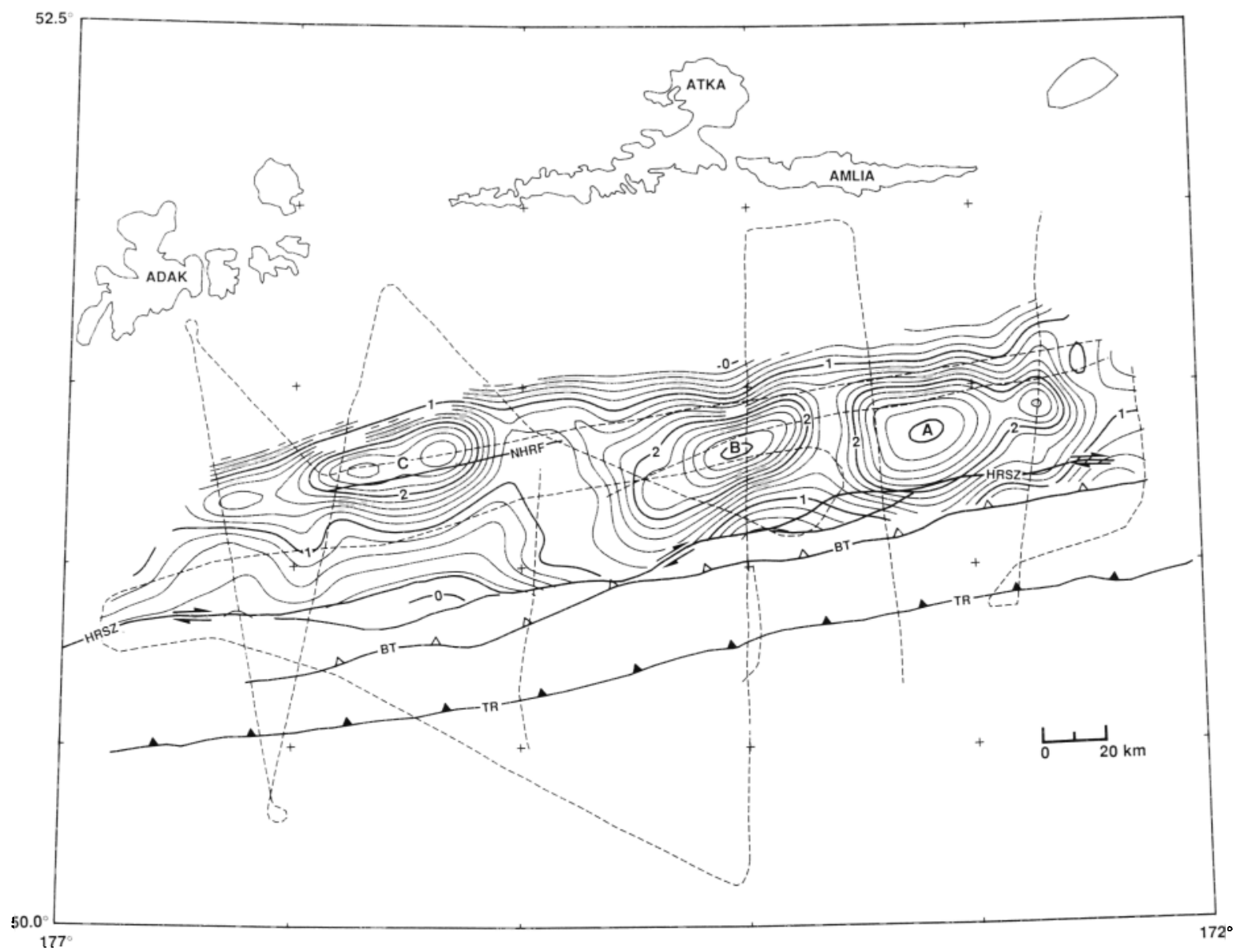

Fig. 5. Isopach map (in kilometers of sediment) of the upper series. There are three major depocenters with more than $2.5 \mathrm{~km}$ of sediment (labeled A, B, and C). The depocenters become younger to the west; the youngest depocenter $(C)$ is farther north due to the relative uplift of Hawley Ridge. The dashed lines are MCS track lines that provided the data base for the isopach map. Bold lines correspond to major faults: BT, backstop thrust; HRSZ, Hawley Ridge shear zone; and NHRF, north Hawley Ridge fault.

trench-slope break that marks the transition from the lower slope of the Aleutian Trench to the relatively flat forearc basin. The most prominent feature of the zone of outer-arc highs is Hawley Ridge, a massive antiform that extends from Adak Canyon eastward to Atka Basin (Figure 2). Hawley Ridge rises as much as $1 \mathrm{~km}$ above the adjacent terrace platform. The ridge narrows at both its east and west ends, and the ridge crest undulates to form a series of bathymetric highs and lows (Figure 2). East of Hawley Ridge the zone of outer-arc highs exhibits much lower bathymetric relief and is not well defined geomorphically.

The zone of structural outer-arc highs is generally underlain by at least two bathymetric highs. The arcward high is underlain primarily by arc basement, whereas the seaward high is also underlain by accreted sediment (Figure 4). The presence of arc basement rocks beneath the zone of outer-arc highs is documented by MCS profiles that show middle series strata and its basement (the lower series) beneath the seaward flank of the forearc basin (Figure 4). Sonobuoy refraction data and interval velocities derived from reflection data record velocities $>5 \mathrm{~km} / \mathrm{s}$. These values support a shallow depth for basement rock below the zone of outer-arc highs. Beneath Hawley Ridge, forearc basin strata have been uplifted and extensionally deformed above arc basement rocks (Figure 7).

A prominent magnetic anomaly that trends east-west along the zone of outer-arc highs also implies the presence of magnetic lower-series rocks, beneath the zone of outer-arc highs. (Figure 4) [Department of Commerce, 1973b]. Magnetic anomalies on the subducting Pacific plate trend east-west, but the observed anomaly is too large in amplitude to be generated by Pacific oceanic crust, which is at a depth of at least $15 \mathrm{~km}$ below the forearc basin [Grow, 1973; McCarthy et al., 1984]. Near the eastern edge of Hawley Ridge, a basement structural high coincides with a $150 \gamma$ circular-shaped positive magnetic anomaly, which corroborates the association of arc basement rocks with magnetic anomalies in the forearc (Figure 7). 

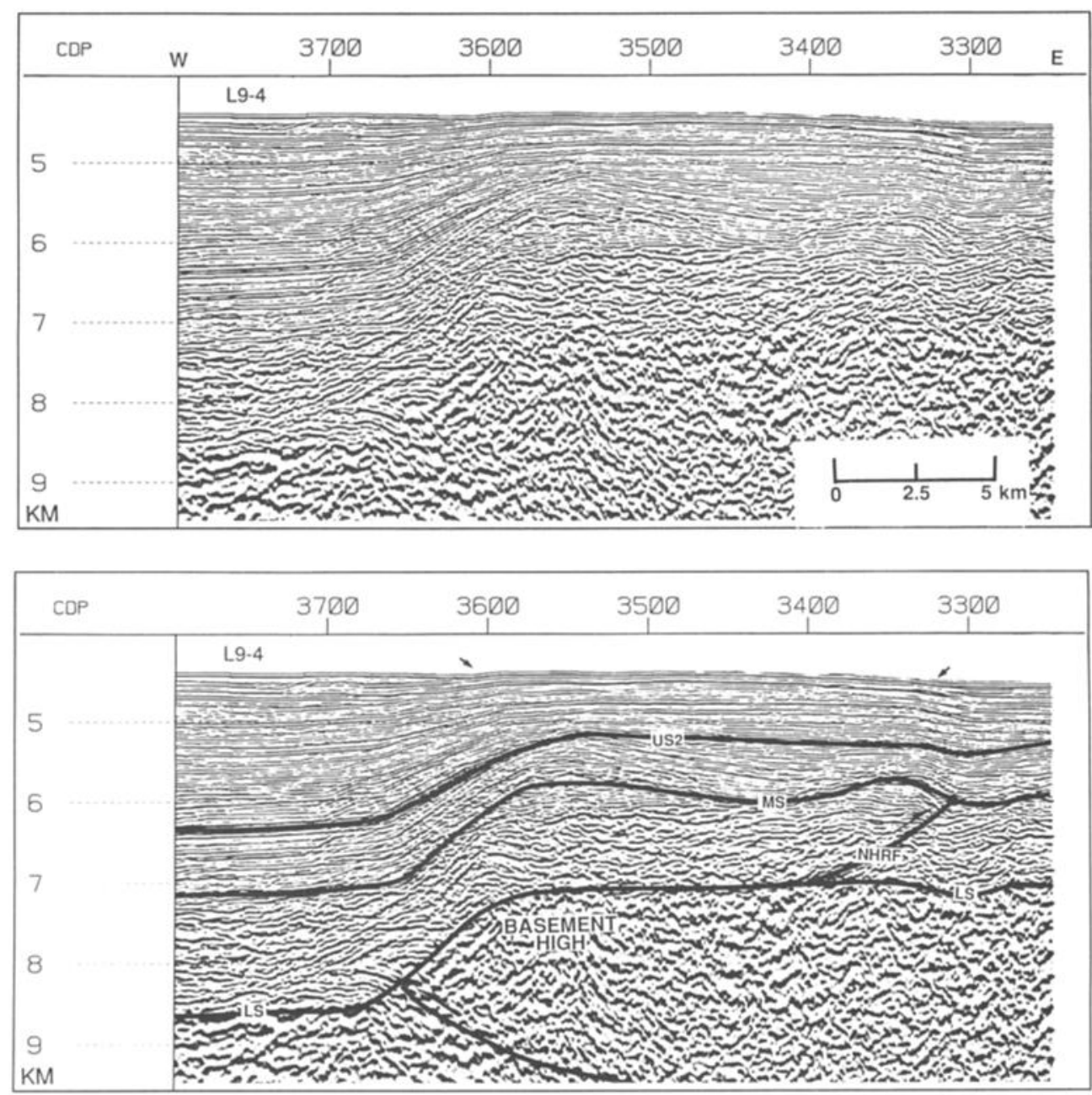

Fig. 6. Portion of profile L9-4, oriented parallel to the margin, showing the thickening of forearc basin strata west of a north striking basement high. A slight seafloor uplift (marked by arrows) is associated with the high, which is located near the epicenter of the 1986 Andreanof earthquake. Subsurface fault near CDP 3350 is the easternmost continuation of the north Hawley Ridge fault (NHRF). A west directed thrust fault within arc basement occurs near CDP 3600. LS, top of lower series; MS, top of middle series; and US2 is a reflector within the upper series discussed in the text. Data are migrated and depth converted. CDP spacing is approximately $50 \mathrm{~m}$. Location of section is shown in Figure $2 a$.

The seaward most of the outer-arc structures is underlain by an accretionary complex of offscraped sediment as much as $8 \mathrm{~km}$ thick (Figure 4) [McCarthy and Scholl, 1985]. The accretionary complex is composed of coherent packets of deposits that dip north from the inner trench wall to the backstop thrust, separating the accretionary complex from arc framework rocks (Figure 4). The backstop thrust that crops out at the seaward edge of the outer-arc high zone is imaged as a shallowly landward dipping surface on most of the MCS profiles (e.g. Figure 8); it strikes approximately parallel to, and at an equal distance from, the trench (Figure $2 \mathrm{~b}$ ).

A zone of noncoherent, high-amplitude, discontinuous reflectors typically occurs north of the outcrop of the backstop thrust ("disrupted reflectors" of Figure 4). Most of these reflectors stack at low velocities, and analyses of shot records show that some of these events are out-of-plane reflectors. Seismic energy scattered off this zone obscures the underlying accretionary complex and associated backstop thrust, which can typically be traced only $5 \mathrm{~km}$ in an arcward direction (Figure 8).

The zone of outer-arc highs is disrupted by young, highangle faults that parallel the trench (Figures 3 and 4). The fault zone is the most prominent forearc feature imaged on GLORIA sonographs and is herein named the Hawley Ridge shear zone (Figure 3). It is continuous for at least $300 \mathrm{~km}$, although the fault becomes less well defined to the east. Geomorphically, the Hawley Ridge shear zone is similar to strike-slip fault zones that have been studied on land [Sylves- 

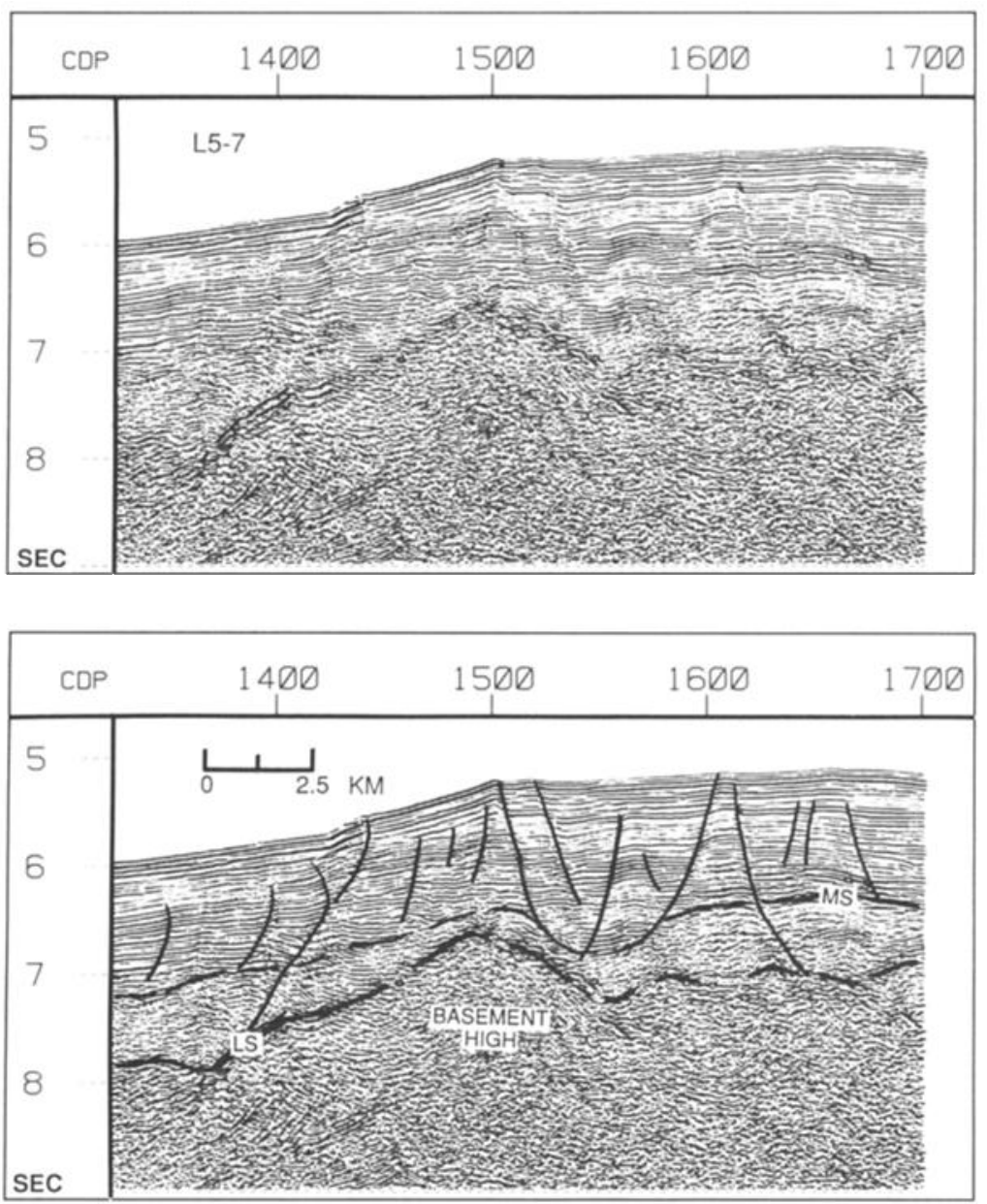

Fig. 7. High-angle and listric normal faults imaged near the eastern end of Hawley Ridge. A $150 \gamma$ magnetic anomaly occurs over the basement high at about CDP 1500. MS, top of the middle series; LS, top of the lower series. Data are migrated using a F-K algorithm; no AGC has been applied to data. CDP spacing is approximately $50 \mathrm{~m}$. Location of section is shown in Figure $2 \mathrm{a}$.

ter, 1988, and references therein]. The fault is composed of relatively linear segments joined by restraining or releasing bends that result in a sinuous fault trace. Prominent features of the shear zone are interpreted to include Riedel shears (RS in Figure 3 inset) and tension fractures (TF in Figure 3 inset).

The character of the shear zone as revealed in MCS data varies considerably along strike; both tensional and compression structures have formed along the fault zone. The western segment of the Hawley Ridge shear zone is marked by a steep-sided bathymetric trough that cuts the southern limb of the Hawley Ridge antiform (Figure 8). A prestack migration of line L9-6, where it crosses the trough, reveals a normal fault with more than $1 \mathrm{~km}$ of dip-slip displacement along the northern flank of the trough (Figure 8). Data collected along L9-10, about $50 \mathrm{~km}$ east of Hawley Ridge, show that the seaward flank of the forearc basin is not as obviously disrupted by high-angle faults (Figure $4 \mathrm{~b}$ ). Here the inner zone of outer-arc highs structures is dominated by thrust faults (Figure 4b). The surficial expression of these faults on a bathymetric map of the area indicate that they trend obliquely to the trench axis [Department of Commerce, 1973a]. These compressional structures may be related to the presence of a restraining bend along the strike-slip fault (Figure 3). Farther eastward, the forearc basin is clearly truncated by a high-angle fault associated with a 600 -m-high scarp and a bathymetric trough (Figure $4 \mathrm{c}$ ). The shear zone is also well imaged on L5-13 (Figure 4d) where forearc basin sediments are disrupted along a high-angle fault.

Unfortunately, the shear zone can typically only be imaged to a depth of about 1-2 km sub-water bottom on the MCS profiles. The lack of reflectors from the shear zone apparently is a characteristic feature of strike-slip faults in general [Lemiszki and Brown, 1988]. We propose that the fault becomes listric at depth and merges with the main thrust zone (Figure 4). The listric nature of the Hawley 

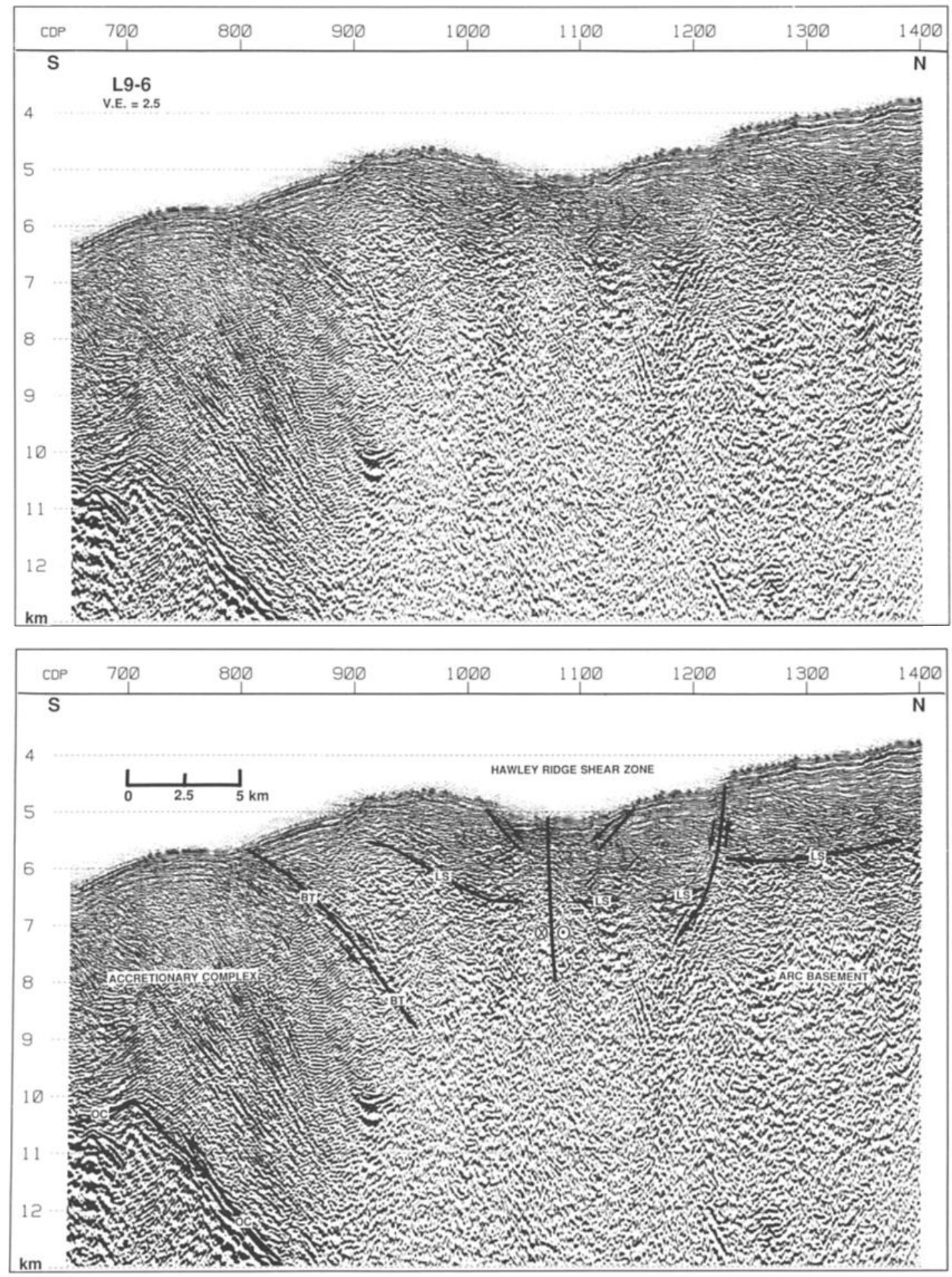

Fig. 8. Hawley Ridge shear zone imaged on profile L9-6 showing normal fault with more than $1 \mathrm{~km}$ of basement offset along the northern edge of the shear zone. These data also show the well-imaged reflectors of the accretionary complex underthrusting arc basement along a landward dipping thrust (BT). Arrows indicate direction of relative movement along faults. LS marks the top of the lower series (arc basement), BT marks the backstop thrust, and OC marks the top of the oceanic crust. Data are migrated and depth converted; no AGC is applied to data. CDP spacing is approximately $50 \mathrm{~m}$. Location of section is shown in Figure $2 \mathrm{a}$. 
Ridge shear zone, with an attendant low-angle basal detachment, is consistent with observations from various welldocumented strike-slip fault zones [e.g., Nicholson et al., 1986; Cheadle et al., 1986; Woodcock and Fischer, 1986]. In addition, since the Aleutian Ridge is deforming as a series of rotating crustal blocks [Geist et al., 1988], a low-angle detachment surface is required beneath the blocks [Nicholson et al., 1986].

The high-angle fault that parallels the shear zone along the northern flank of Hawley Ridge is herein named the north Hawley Ridge fault (Figure 2b). This fault can be traced for about $50 \mathrm{~km}$ on seismic reflection profiles from L9-6 (Figure 4a) to the east end of Hawley Ridge (Figure 6). Although the fault does not reach the seafloor, a small seafloor flexure is present across the fault, and it shows a reverse sense of motion (Figures 4a and 6). The east end of the fault is present near the transverse basement high at the east edge of Hawley Ridge (Figure 6). North of the fault the arcward (northern) flank of the forearc basin is tilted about $2^{\circ}-3^{\circ}$ seaward (Figure 4a).

\section{FOREARC EVOLUTION}

The lower series formed during the initial igneous constructional phase of the arc massif, from roughly 55 to 37 Ma [Scholl et al., 1987]. During most of lower series time the Kula plate rapidly underthrust the North American plate possibly at rates as high as $200 \mathrm{~km} / \mathrm{m}$.y. at a direction nearly orthogonal to the trench axis [Engebretson et al., 1986; Lonsdale, 1988]. This convergence continued until approximately $43 \mathrm{Ma}$, when a major change in Pacific plate motions, as manifest by the bend in the Hawaiian-Emperor seamount chain [Clague, 1981], resulted in a waning of arc volcanism [Scholl et al., 1987]; spreading ceased at the Kula-Pacific ridge, and the Kula plate was welded to the Pacific plate [Engebretson et al., 1986; Lonsdale, 1988]. The change in plate motions resulted in a decrease in rate and an increase in obliquity of motion between the Pacific and North American plates along the Aleutian Ridge during the time of middle series deposition.

We have been unable to recognize evidence that an early or middle Tertiary accretionary complex of offscraped trench deposits formed along the central Aleutian forearc; the early Tertiary Aleutian Trench was evidently sediment starved. In the forearc area of the central Aleutian Arc the middle series does not thicken appreciably except locally along a narrow zone at the north edge of the Aleutian Terrace. A geomorphically prominent forearc basin, similar to that currently underlying the Terrace, probably did not exist in Oligocene and Miocene time. Lower series rocks with a mantle of middle series deposits extended more or less continuously to the trench. If an older accretionary complex formed, its remnants are volumetrically small and/or so structurally deformed as to be unrecognizable (e.g., "disnupted reflectors" on Figure 4). Altematively, a paleoforearc basin and accretionary complex may have been present along the margin, but both were subsequently removed by either strike-slip faulting or subduction erosion.

A major change in the structural evolution of the forearc occurred in late Miocene to early Pliocene time. At approxi- mately $5 \mathrm{Ma}$, a change in plate motions caused slightly faster and more orthogonal subduction at the central Aleutian Trench [Engebretson et al., 1986]. Roughly contemporaneously, alpine glaciation in Gulf of Alaska drainages [Armentrout et al., 1978] resulted in the deposition of voluminous turbidites in the central Aleutian Trench. A consequence of more orthogonal and faster subduction and, more importantly, the arrival of axially transported sediment to the trench, was the formation of an accretionary complex and structurally linked forearc basin [McCarthy et al., 1984; McCarthy and Scholl, 1985; Harbert et al., 1986].

Initial outer-arc structures formed as the result of the underthrusting of the accretionary complex beneath older arc framework rocks (lower series) along an arcward dipping backstop thrust. An arcward dipping structural backstop requires that arc basement and overlying forearc basin strata are uplifted, along with the boundary fault itself, without the formation of major seaward dipping thrust faults [Silver and Reed, 1988]; this is consistent with structures observed in the central Aleutian forearc. A high-angle reverse fault does occur on the arcward side of Hawley Ridge (the north Hawley Ridge fault), but the fault is a localized feature (see below) that cannot account for the general uplift of outer forearc structures.

\section{EFFECTS OF OBLIQUE SUBDUCTION ON OUTER-ARC HIGH DEFORMATION}

Since at least Oligocene time, convergence along the Aleutian Trench has been oblique to the strike of the margin [Engebretson et al., 1986]. Near Atka Island there is currently about a $30^{\circ}$ component of obliquity that progressively increases to the west; relative plate motions in the far westem Aleutians approximate pure strike slip [Minster and Jordan, 1978]. Geist et al. [1988] show that summit basins along the crest of the Aleutian arc are trailing edge grabens formed behind clockwise-rotating blocks of the arc massif in response to oblique subduction (Figure 1). The region between the east end of Amukta Basin (about longitude $171.5^{\circ} \mathrm{W}$ ) and Adak Canyon (at the west end of Hawley Ridge) is defined as the Andreanof block (Figure 1) [Spence, 1977; Geist et al., 1988].

We propose that the Hawley Ridge shear zone is the southern margin of the Andreanof block. The shear zone formed arcward of the backstop thrust where the Pacific plate (including subducted sediment) is in direct contact with overlying arc massif rocks of the North American plate (Figure 9). The accretionary complex, which is located primarily seaward of the shear zone, is presumably moving laterally past Hawley Ridge and other related structures that are inboard of the shear zone. In addition, slivers of truncated forearc rocks appear to be shunted along the shear zone as strike-slip duplexes [Woodcock and Fischer, 1986]. For example, the oblong feature beneath "RS" in Figure 3a may be a strike-slip duplex, bound by Riedel shears, that is moving westward along the shear zone.

The eastem and western parts of the Andreanof block have developed distinct structural styles (Figure 9), which suggest that the block may be deforming internally in response to oblique subduction. Along the eastern sector of the 


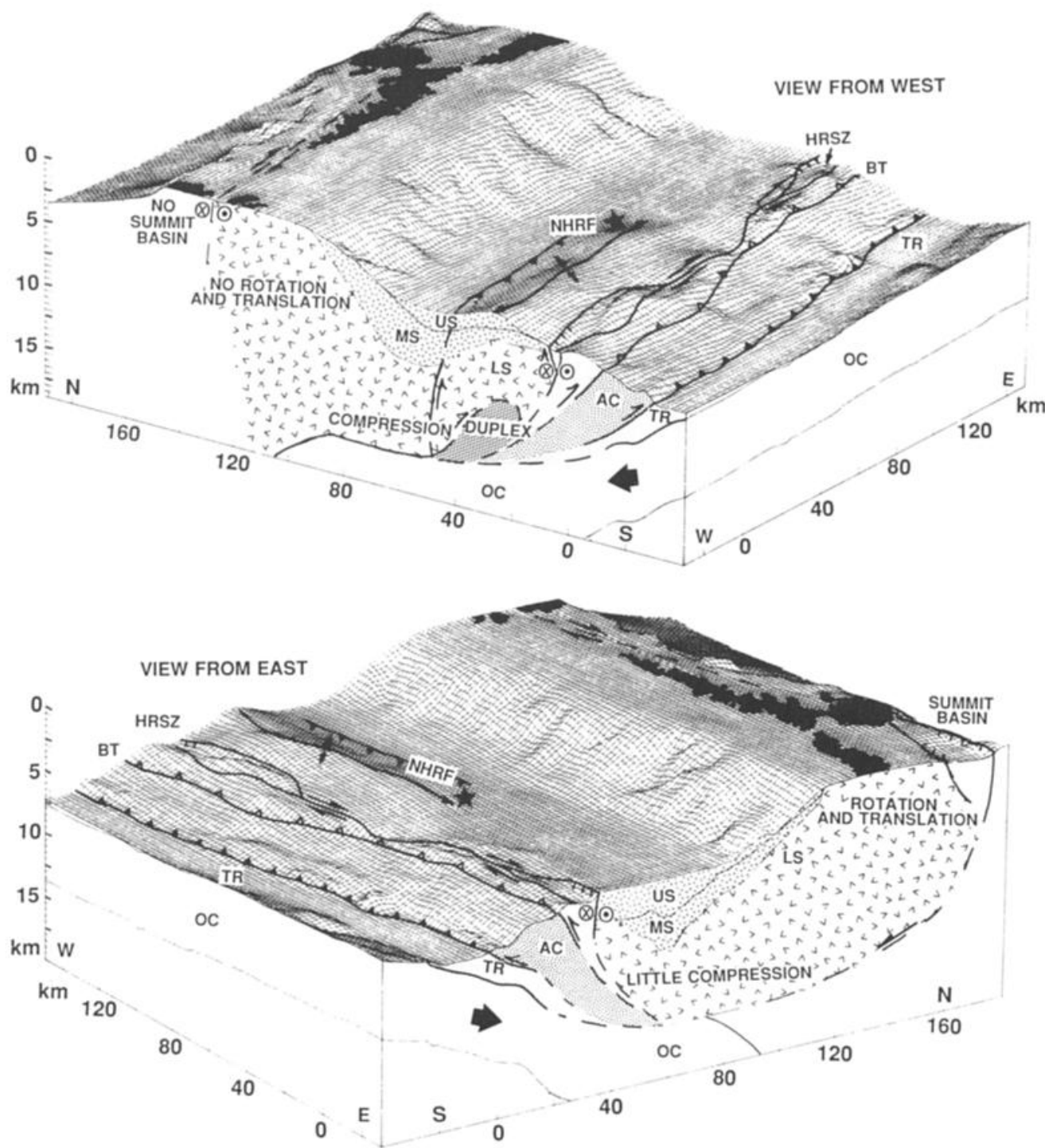

Fig. 9. Block diagram illustrating the differences in deformation between the western and eastern sectors of the Andreanof block. The forearc in the western Andreanof block (top) is characterized by compressive deformation oriented in both north-south (e.g., NHRF) and east-west (associated with laterally transported anc basement and internal deformation associated with the lack of rotation of the western Andreanof block) directions. The forearc in the eastern Andreanof block (bottom) is characterized by (1) block rotation and the opening of an extensional summit basin and (2) the truncation and removal of arc basement rocks that results in a much narrower zone of outer-arc highs. North of the accretionary complex there is little evidence for compressive deformation of the eastern sector. US, upper series; MS, middle series; LS, lower series (arc basement); HRSZ, Hawley Ridge shear zone; NRHF, north Hawley Ridge fault; BT, backstop thrust; AC, accretionary complex; TR, trench deposits and subducted sediment. Zone of disrupted reflectors between arc basement and accretionary complex is shown by cross-hatched pattern. The duplex structure (top) is probably composed of laterally-transported arc basement rock and perhaps also of underplated sediment. The star shows the location of the 1986 Andreanof earthquake. Bathymetry is from Department of Commerce [1973a] and subsurface data are constrained from MCS data at approximately the locations of Figure 4a (L9-6) and Figure 4b (L9-12).

Andreanof block (1) Amlia and Amukta summit basins have opened in response to block rotation linked to oblique convergence [Geist et al., 1988], (2) a large forearc basin (Atka Basin) is present, but there is no large Hawley Ridge-type outer-arc structure along the margin, (3) the seaward edge of the forearc basin is truncated, and (4) there is little evidence for compressive deformation arcward of the backstop thrust (Figure 9). 
The major features of the western Andreanof block include (1) the lack of a summit basin, (2) the uplift of Hawley Ridge, which is the largest of the active structures within the zone of outer-arc highs, and (3) evidence for compressive deformation of the forearc arcward of Hawley Ridge. The high-angle reverse fault along the north flank of Hawley Ridge (north Hawley Ridge fault) and the seaward tilt of the northem flank of the forearc basin behind Hawley Ridge (e.g. Figure 4a), suggest that the Hawley Ridge segment of the forearc is compressively deformed. However, the formation of Hawley Ridge does not appear to be simply ascribed to compression related to the accretion and underplating of a greater amount of sediment beneath the ridge. Neither the width nor thickness of the accretionary complex varies significantly along strike; the along-strike outcrop trace of the boundary thrust occurs roughly equidistant from the trench (Figure 5). In fact, the location of the maximum thickness of sediment in the trench, which occurs near the Amlia Fracture Zone, is in the eastem part of the Andreanof block [Scholl et al., 1982]. Thus the physical dimensions of the accretionary complex appear to be unrelated to the style and dimensions of outer-arc structures.

The presence to the east of Hawley Ridge of a companion structural basin, Atka Basin, that is not bordered by a large outer-arc high, suggests that the origin of the two coeval structures is related to the thickness of arc basement beneath them. Profile L9-8, collected along the crest of Hawley Ridge and across Atka Basin, does not show thrust thickening of upper and middle series beds. Crustal thickening beneath Hawley Ridge is therefore limited to rocks accumulating below blind thrusts that uplift, but do not thicken, middle and upper series beds. We suggest that the basement thickening is controlled by duplexes transporting material westward beneath roof thrusts and floor thrusts that merge at depth with the main zone of plate underthrusting (Figure 9). The westward migration of the forearc basin depocenter may be related to this westward transport of basement duplexes.

Hawley Ridge is also unique in that the only recorded earthquakes in the seismically quiet zone between the trench and Aleutian Terrace forearc basin [Chen et al., 1982] occur beneath the arcward side of Hawley Ridge (S. Billington and J. R. Bowman, personal communication, 1987). In addition, great thrust-type earthquakes (magnitude $>8$ ) occurred in 1957 and 1986 along the plate boundary below the northeast end of Hawley Ridge [Hwang and Kanamori, 1986]. The area of aftershocks of the 1986 earthquake forms a welldefined seismic front [Byrne et al., 1988; Engdahl et al., 1989] that corresponds in location to the Hawley Ridge shear zone. The earthquake ruptured bilaterally away from the main event (location shown in Figure 9); more than twice as much moment was released from the western (Hawley Ridge) segment of the forearc [Engdahl et al., 1989]. The earthquake data support the contention that the shear zone forms a major structural boundary and that greater amounts of stress can accumulate along the main thrust zone beneath the western Andreanof block.

We propose that the Andreanof block may be tearing into eastern and western segments somewhere near the earthquake epicenter. Because no summit basins or transverse faultcontrolled canyons have deformed the summit platform north of Hawley Ridge, block rotation has not occurred here, and stress related to oblique plate motion must be taken up by the internal deformation of the arc massif. The reason that the western Andreanof block has greater strength and resistance to shearing and block rotation than the eastern block may be because of the unusual occurrence of multiple and large epizonal plutons that intruded the arc north of Hawley Ridge and significantly metamorphosed lower-series rocks of the arc massif [Kay, 1983]. Interestingly, the entire forearc west of the Hawley Ridge segment of the Andreanof block (the Delarof block; Figure 1) is extensively slivered by transverse faults related to the tearing and rotation of the forearc in response to oblique plate convergence [Geist et al., 1988], which suggests that the Delarof block is mechanically weaker and offers less resistance to shearing.

Although the Hawley Ridge shear zone is present along a primarily convergent plate boundary, it has characteristics that are remarkedly similar to the San Andreas fault in California. Geomorphically, both fault zones are present beneath a linear valley within a topographically hilly area [Allen, 1981]. Geophysically, both fault zones are characterized by negative gravity anomalies, low seismic velocities, and elongated, though discontinuous, magnetic anomalies [Stierman, 1984; Wang, 1984]. Evidence is accumulating that the San Andreas fault system is a mechanically weak zone that allows for the transmission of compressive stress, oriented perpendicular to its trend [Zoback et al., 1987; Mount and Suppe, 1987]. Similarly, compression related to the subduction of the Pacific plate beneath the central Aleutians is transmitted across the mechanically weak Hawley Ridge shear zone such that coeval compressive and shear stresses deform the forearc.

The implications of coeval strike-slip faults and thrust faults along a margin with only $30^{\circ}$ of oblique convergence are important for the interpretation of rocks formed along paleoconvergent margins. As Karig et al. [1986] and Jarrard [1986] suggest, strike-slip faulting may be more important to forearc deformation along obliquely convergent margins than previously considered. For example, highly sheared and/or serpentinized rocks that formed within a high-angle shear zone adjacent to an accretionary complex could be mistakenly identified as fragments of ophiolite accreted to a margin [Karig et al., 1986]. It is interesting to note that Jayko et al. [1987] recently reinterpreted the Coast Range "thrust" separating the Franciscan Complex from upper plate rocks in California to be a high-angle fault zone with a complex history of compressional, strike-slip, and extensional movement.

\section{CONCLUSIONS}

The central Aleutian Arc evolved initially in Eocene time as an intraoceanic island arc bordered by a sediment-starved trench. During Oligocene and Miocene time, volcanism significantly diminished, and thick slope-mantling strata were deposited on the flanks of the Aleutian ridge. However, the lack of basinal thickening of these strata indicates that a zone of outer-arc structural highs and associated forearc basin were not prominent structural features at this time. If an accretionary complex was present beneath the landward trench slope, it was either volumetrically small or all remnants have been removed or incorporated indistinguishably into the arc's basement fabric. A significant change in the configuration of the forearc occurred at about $5 \mathrm{Ma}$, when 
voluminous sediment from mainland Alaska was transported via the trench to the central Aleutian region. Mildly deformed, coherent packages of trench sediment were thrustthickened and accreted to the forearc beneath a north or arcward dipping thrust fault. The underthrusting of trench sediment uplifted the seaward flank of the arc massif and formed the initial structures of the zone of outer-arc highs. The forearc basin of the Aleutian Terrace formed as a consequence of this uplift, and it is therefore underlain by the igneous arc massif and older slope-mantling strata.

The zone of outer-arc highs evolved initially above a lowangle, arcward dipping thrust fault, although subsequent deformation related to the evolution of a major shear zone induced by the oblique component of convergence between the Pacific and North American plates obscures this relationship. Normal, strike-slip, and high-angle reverse faults associated with the shear zone have contributed to the continued deformation of outer-arc high structures. Slivers of forearc rock are transported along the shear zone, and our data suggest that along strike movement of arc basement duplexes beneath the forearc basin also occurs. In addition, deformation related to oblique convergence results in the incipient sundering of the arc along transverse structures.

Modem subduction zones are commonly affected by a tectonically significant component of oblique convergence. It is therefore reasonable to suppose that lengthy sectors of ancient ocean margins not only evolved in similar tectonic settings but formed adjacent to trenches with thick accumulations of turbidite deposits. If these conditions prevailed for any length of time, then exceptionally complex forearc structures and structural relations would evolve. Included among them would be the coevolution of compressional, extensional, and strike-slip structures. Perhaps equally perplexing would be field evidence for the contemporaneous growth of an accretionary wedge and a more landward assemblage of tectonostratigraphic terranes fronting forearc basinal deposits. Some of the transported blocks could be fragments of exotic material but most would be tectonically kindred splinters of ocean margin igneous and sedimentary rocks.

Acknowledgments. We would like to thank Carolyn Degnan for her help in preparing the the block diagrams. We thank Bob Bohannon (especially) and Steve Lewis for reviews of an earlier version of this manuscript and Tectonics reviewers Eli Silver, Jill McCarthy, and an anonymous reviewer for their constructive criticisms.

\section{REFERENCES}

Allen, C. R., The modern San Andreas fault, in The Geotectonic Development of California, Rubey vol. 1, edited by W. G. Ernst, pp. 511-534, Prentice-Hall, Englewood Cliffs, N. J., 1981.

Armentrout, J. M., R. J. Echols, and K. W. Nash, Late Neogene cycles of the Yakataga formation, Robinson Mountains, Gulf of Alaska arc, in Correlation of Tropical Through High-Latitude Marine Deposits of the Pacific Basin, vol. 14, edited by W. O. Addicott and J. C. Ingle, pp. 3-4, Stanford University Press, Stanford, Calif., 1978.
Beck, M. E., Jr., Model for late Mesozoic-early Tertiary tectonics of coastal California and western Mexico and speculations on the origin of the San Andreas fault, Tectonics, 5 , 49-64, 1986.

Bohannon, R. G., M. R. Dobson, B. D. Edwards, and C. L. Jacobs, Tectonics of north Pacific ocean basin, western Aleutian Island region (abstract), Eos Trans. AGU, 68, 1486, 1987.

Brandon, M. T., Comment on "Comments on the growth of accretionary wedges," Geology, 14, 184-185, 1986.

Byme, D. E., D. M. Davis, and L. R. Sykes, Loci and maximum size of thrust earthquakes and the mechanics of the shallow region of subduction zones, Tectonics, 7, 833-858, 1988.

Cheadle, M. J., B. L. Czuchra, T. Byme, C. J. Ando, J. E. Oliver, L. D. Brown, S. Kaufman, P. E. Malin, and R. A. Phinney, The deep crustal structure of the Mojave Desert, California, from COCORP seismic reflection data, Tectonics, 5, 293-320, 1986.

Chen, A. T., C. Frohlich, and G. V. Latham, Seismicity of the forearc marginal wedge (accretionary prism), J. Geophys. Res., 87, 3679-3690, 1982.

Citron, G. P., R. W. Kay, S. M. Kay, L. W. Snee, and J. F. Sutter, Tectonic significance of early Oligocene plutonism on Adak Island, central Aleutian Islands, Alaska, Geology, 8, 375-379, 1980.

Clague, D. A., Linear island and seamount chains, aseismic ridges and intraplate volcanism; results from DSDP, Spec. Publ. Soc. Econ. Paleontol. Mineral., 32, 7-22, 1981.

Creager, J. S., et al., Initial Rep. Deep Sea Drill. Proj., 19, U.S. Govt. Print. Office, Washington, D. C., 1973.

Davis, D., J. Suppe, and F. A. Dahlen, The mechanics of fold-and-thrust belts and accretionary wedges, $J$. Geophys. Res., 88, 1153-1172, 1983.

Department of Commerce, NOS Seamap Ser., 16,648-14B, Pacific Ocean, scale 1:1,000,000, Nat. Oceanic and Atmos. Admin., Washington, D. C., 1973a.

Department of Commerce, NOS Seamap Ser., 16,648-14M, Pacific Ocean, scale 1:1,000,000, Nat. Oceanic and Atmos. Admin., Washington, D. C., 1973b.

Dickinson, W. R., and D. R. Seeley, Structure and stratigraphy of forearc regions, Am. Assoc. Pet. Geol. Bull., 63, 231, 1979.

Engdahl, E. R., S. Billington, and C. Kisslinger, Teleseismically recorded seismicity before and after the May 7, 1986, Andreanof Islands, Alaska, earthquake, J. Geophys. Res., in press, 1989.

Engebretson, D. C., A. Cox, and R. G. Gordon, Relative motions between oceanic and continental plates in the Pacific Basin, Spec. Pap. Geol. Soc. Am., 206, 59 pp., 1986.

Fitch, T. J., Plate convergence, transcurrent faults, and the internal deformation adjacent to Southeast Asia and the western Pacific, J. Geophys. Res., 77, 4432-4461, 1972.

Geist, E. L., J. R. Childs, and D. W. Scholl, The origin of summit basins of the Aleutian Ridge, Implications for block rotation of an arc massif, Tectonics, 7, 327-342, 1988.

Grim, P. J., and B. H. Erickson, Fracture zones and magnetic anomalies south of the Aleutian Trench, J. Geophys. Res., 74, 1488-1494, 1969. 
Grow, J. A., Crustal and upper mantle structure of the central Aleutian arc, Geol. Soc. Am. Bull., 84, 2169-2192, 1973.

Harbert, W., D. W. Scholl, T. L. Vallier, A. J. Stevenson, and D. M. Mann, Major evolutionary phases of a forearc basin of the Aleutian terrace: Relation to north Pacific tectonic events and the formation of the Aleutian subduction complex, Geology, 14, 757-761, 1986.

Hwang, L. J., and H. Kanamori, On the May 7, 1986 Andreanof Islands earthquake source parameters, Geophys. Res. Lett., 13, 1426-1429, 1986.

Jarrard, R. D., 1986, Terrane motion by strike-slip faulting of forearc slivers, Geology, 14, 780-783, 1986.

Jayko, A. S., M. C. Blake, Jr., and T. Harms, Attenuation of the Coast Range ophiolite by extensional faulting, and nature of the Coast Range "thrust, Califomia, Tectonics, 6, 475-488, 1987.

Karig, D. E., and G. F. Sharman, Subduction and accretion at trenches, Geol. Soc. Am. Bull., 86, 377-389, 1975.

Karig, D. E., D. R. Sarewitz, and G. D. Haeck, Role of strike-slip faulting in the evolution of allochthonous terranes in the Philippines, Geology, 14, 852-855, 1986.

Kay, S. M., Metamorphism in the Aleutian arc: The Finger Bay pluton, Adak, Alaska, Can. Mineral., 21, 665-681, 1983.

Lemiszki, P. J., and L. D. Brown, Variable crustal structure of strike-slip fault zones as observed on deep seismic reflection profiles, Geol. Soc. Am. Bull., 100, 665-676, 1988.

Le Pichon, X., N. Lyberis, J. Angelier, and V. Renard, Strain distribution over the Mediterranean ridge: A synthesis incorporating new sea-beam data, Teclonophysics, 86, 243-274, 1982.

Lewis, S. D., J. W. Ladd, and T. R. Bruns, Structural development of an accretionary prism by thrust and strike-slip faulting: Shumagin region, Aleutian Trench, Geol. Soc. Am. Bull., 100, 767-782, 1988.

Lonsdale, P., Paleogene history of the Kula plate-Offshore evidence and onshore implications, Geol. Soc. Am. Bull. 100, 733-754, 1988.

McCarthy, J., and D. W. Scholl, Mechanisms of subduction accretion along the central Aleutian Trench, Geol. Soc. Am. Bull., 96, 691-701, 1985.

McCarthy, J., A. J. Stevenson, D. W. Scholl, and T. Vallier, Speculations on the petroleum geology of the accretionary body: An example from the central Aleutians, Mar. Pet. Geol., 1, 151-167, 1984.

Minster, J. B., and T. H. Jordan, Present-day plate motions, J. Geophys. Res., 83, 5331-5354, 1978.

Moore, J. C., and E. A. Silver, Continental margin tectonics: Submarine accretionary prisms, Rev. Geophys., 25, 13051312, 1987.

Mount, V. S., and J. Suppe, State of stress near the San Andreas fault: Implications for wrench tectonics, Geology, 15, 1143-1146, 1987.

Nicholson, C., L. Seeber, P. Williams, and L. R. Sykes, Seismicity and fault kinematics through the eastern Transverse Ranges, California: Block rotation, strike-slip faulting, and low-angle thrusts, J. Geophys. Res., 91, 4891-4908, 1986.

Rubenstone, J. L., Geology and geochemistry of early Tertiary submarine volcanic rocks of the Aleutian Islands and their bearing on the development of the Aleutian Island Arc, Ph.D. thesis, Cornell Univ., Ithaca, N. Y., 1984.

Scholl, D. W., T. L. Vallier, and A. J. Stevenson, Sedimentation and deformation in the Amlia fracture zone sector of the Aleutian Trench, Mar. Geol., 48, 105-134, 1982.

Scholl, D. W., T. L. Vallier, and A. J. Stevenson, Arc, forearc, and trench sedimentation and tectonics; Amlia corridor of the Aleutian Ridge, in Studies in Continental Margin Geology, Mem. 34, edited by J. S. Watkins, and C. L. Drake, pp. 413-439, American Association of Petroleum Geologists, Tulsa, Okla., 1983a.

Scholl, D. W., T. L. Vallier, and A. J. Stevenson, Geologic evolution of the Aleutian Ridge-Implications for petroleum resources, J. Alaska Geol., 3, 33-46, $1983 \mathrm{~b}$.

Scholl, D. W., T. L. Vallier, and A. J. Stevenson, Geologic evolution and petroleum potential of the Aleutian ridge, in Geology and Resource Potential of the Continental Margin of Western North America and Adjacent Ocean BasinsBeaufort Sea to Baja California, Earth Sci. Ser., vol. 6, edited by D. W. Scholl, A. Grantz, and J. G. Vedder, pp. 123-156, Circum-Pacific Council for Energy and Mineral Resources, Houston, Tex., 1987.

Seeley, D. R., The evolution of structural highs bordering major forearc basins, in Geology and Geophysical Investigations of Continental Margins, Mem. 29, edited by J. S. Watkins and L. Montadert, pp. 245-260, American Association of Petroleum Geologists, Tulsa, Okla., 1978.

Silver, E. A., and D. L. Reed, Backthrusting in accretionary wedges, J. Geophys. Res., 93, 3116-3126, 1988.

Silver, E. A., M. J. Ellis, N. A. Breen, and T. H. Shipley, Comments on the growth of accretionary wedges, Geology, 13, 6-9, 1985.

Spence, W., The Aleutian arc, tectonic blocks, episodic subduction, strain diffusion, and magma generation, $J$. Geophys. Res., 82, 213-230, 1977.

Stierman, D. J., Geophysical and geological evidence for fracturing, water circulation, and chemical alteration in granitic rocks adjacent to major strike-slip faults, $J$. Geophys. Res., 89, 5849-5857, 1984.

Sylvester, A. G., Strike-slip faults, Geol. Soc. Am. Bull., 100, 1666-1703, 1988.

Vallier, T. L., D. W. Scholl, M. A. Fisher, T. R. Bruns, and $R$. von Huene, Geologic framework of the Aleutian structural arc, Alaska, in Cordilleran Orogen, Alaska, Decade N. Am. Geol., Ser., edited by G. Plafker and D. L. Jones, Geological Society of America, Boulder, Colo., 1989.

von Huene, R., E. Suess, and Leg 112 Shipboard Scientists, Ocean Drilling Program Leg 112, Peru continental margin; 1, Tectonic history, Geology, 16, 934-938, 1988.

Wang, C.-Y., 1984, On the constitution of the San Andreas fault zone in central California, J. Geophys. Res., 89 , 5858-5866, 1984.

Westbrook, G. K., J. W. Ladd, P. Buhl, N. Bangs, and G. J. Tiley, Cross section of an accretionary wedge: Barbados Ridge complex, Geology, 16, 631-635, 1988.

Woodcock, N. H., and M. Fischer, Strike-slip duplexes, $J$. Struct. Geol., 8, 725-735, 1986.

Zoback, M. D., and C. M. Wentworth, Crustal studies in central California using an 800-channel seismic reflection recording system, in Reflection Seismology: A Global Per- 
spective, Geodyn. Ser., vol. 13, edited by M. Barazangi and L. Brown, pp. 183-196, 1986.

Zoback, M. D., M. L. Zoback, V. S. Mount, J. Suppe, J. P. Eaton, J. H. Healy, D. Oppenheimer, P. Reasenberg, L. Jones, C. B. Raleigh, I. G. Wong, O. Scotti, and C. Wentworth, New evidence on the state of stress of the San Andreas fault system, Science, 238, 1105-1111, 1987.
H. F. Ryan and D. W. Scholl, U. S. Geological Survey, 345 Middlefield Road, MS 999, Menlo Park, CA 94025.

(Received September 16, 1988;

revised January 13, 1989;

accepted January 13, 1989.) 